Syntax Fusion: Jurnal Nasional Indonesia

e-ISSN: 2775-4440

Vol. 1, No. 10, Oktober 2021

\title{
PENGARUH HARGA DAN KUALITAS PRODUK TERHADAP LOYALITAS PELANGGAN
}

\section{Nisa Septiani}

Sekolah Pascasarjana, Program Studi Magister Manajemen, Universitas Widyatama

Email: septianiisa@gmail.com

\begin{abstract}
Abstrak
Menurut pengamatan pada tahun lalu, banyak perkembangan toko fashion muslim di Bandung meningkat pesat. Kompetisi toko pakaian Muslim di wilayah Bandung juga meningkat pesat. Penelitian ini mencoba untuk mengungkapkan beberapa formulasi masalah yaitu: Mengetahui harga produk menurut konsumen PT Shafira Corporation, Mengetahui kualitas produk menurut konsumen PT Shafira Corporation, mengetahui loyalitas pelanggan menurut konsumen PT Shafira Corporation, mengetahui dan menguji efek kualitas produk terhadap loyalitas pelanggan menurut nasabah PT Shafira Corporation, untuk mengetahui dan menguji efek harga dan kualitas produk terhadap loyalitas pelanggan sesuai dengan pelanggan PT Shafira Corporation. Metode yang digunakan adalah metode deskriptif. Penelitian desain menggunakan Desain Korelasional. Metode pengumpulan data termasuk wawancara, kuesioner, dan pengamatan. Analisis data menggunakan Uji Validitas, Uji Keandalan, Tes Asumsi Klasik, Tes Normalitas, dan Tes Multikolinearitas. Analisis regresi menggunakan Regresi Linier Berganda. Penelitian dilakukan di Outlet Shafira Buah Batu Cabang Bandung. Populasi adalah konsumen dari PT Shafira Corporation. Sampel diambil menggunakan convenience sampling berjumlah 150 konsumen.
\end{abstract}

Kata Kunci: Harga; Kualitas Produk; Loyalitas Pelanggan

Diterima: 24-09-2021 Direvisi: 15-10-2021 Disetujui: 18-10-2021

\section{Pendahuluan}

Persaingan dalam dunia fashion muslim akhir-akhir ini menunjukkan bahwa kebutuhan dan perubahan gaya hidup masyarakat semakin meningkat dan mereka semakin peduli dengan penampilan yang disesuaikan dengan perkembangan zaman. Bisa dikatakan bahwa perilaku pembelian seseorang adalah unik karena setiap orang memiliki preferensi dan sikap yang berbeda terhadap suatu barang. Oleh karena itu, produsen perlu memahami perilaku konsumen terhadap produk atau merek yang ada di perusahaan, yang kemudian perlu dilakukan dengan berbagai cara agar konsumen tertarik dengan produk yang 
diproduksi.

Menurut Kotler dan Armstrong pada dasarnya kebutuhan dan keinginan konsumen selalu berubah bahkan cenderung meningkat dari waktu ke waktu, sehingga perusahaan perlu melakukan riset pemasaran untuk mengetahui produk apa yang sebenarnya dibutuhkan dan diinginkan oleh konsumen. kesetiaan pelanggan. Kualitas produk merupakan faktor penting dalam menciptakan kepuasan pelanggan (Kotler \& Keller, 2009). Kualitas produk merupakan faktor penentu kepuasan konsumen setelah membeli dan menggunakan produk. Menurut Alma, kualitas produk merupakan suatu bentuk dengan nilai kepuasan yang kompleks. Dengan kualitas produk yang baik maka keinginan dan kebutuhan konsumen akan produk tersebut akan terpenuhi. Jika kualitas produk yang diperoleh lebih tinggi dari yang diharapkan, maka persepsi kualitas produk akan memuaskan (Alma, 2005).

Berdasarkan teori dan hasil penelitian sebelumnya yang menunjukkan bahwa harga dan kualitas produk mempengaruhi loyalitas pelanggan, diperlukan penelitian lebih lanjut untuk memastikan hasil penelitian tersebut. Menurut Kotler harga adalah jumlah yang dibebankan untuk suatu produk atau jasa. Lebih luas lagi, harga adalah nilai total yang ditukar konsumen atas manfaat memiliki suatu produk atau jasa (Kotler \& Keller, 2009), sedangkan menurut Ghozali, harga adalah satuan uang atau ukuran lain (termasuk barang dan jasa lain) yang ditukar dengan tujuan memiliki produk atau jasa, memperoleh hak milik atau menggunakan barang atau jasa (Ghozali, 2010).

Harga merupakan faktor yang dapat mempengaruhi konsumen ketika membeli suatu produk/jasa yang diinginkan. Konsumen akan melihat terlebih dahulu harga yang tertera pada produk, karena sebelum membeli, konsumen memikirkan sistem tabungan yang cocok. Selain itu, konsumen mungkin memikirkan harga yang ditawarkan tergantung pada produk yang dibeli.

Menurut Kotler dan Amstrong, ada empat dimensi mencirikan harga yaitu:

1. Keterjangkauan harga

2. Kesesuaian harga dengan kualitas produk

3. Daya saing harga

4. Kesesuaian harga dengan manfaat

Menurut Kotler, kualitas produk adalah kemampuan suatu produk untuk melakukan suatu fungsi: Sifat-sifat ini meliputi daya tahan, keandalan, akurasi yang dihasilkan, kemudahan pemeliharaan dan perbaikan, dan atribut berharga lainnya dari produk sebagai utuh (Kotler \& Keller, 2009).

Goetsch dan Davis berpendapat bahwa kualitas produk adalah keadaan dinamis dari barang, jasa, orang, produk dan lingkungan yang memenuhi atau melebihi harapan. Sedangkan menurut A.V Feigenbaum, kualitas produk adalah keseluruhan kombinasi karakteristik barang dan jasa dari pemasaran, rekayasa, produksi dan pemeliharaan, yang meliputi barang dan jasa yang digunakan untuk memenuhi harapan pelanggan. 
Menurut Mullins, Orville, Larreche, dan Boyd, jika sebuah perusahaan ingin mempertahankan keunggulan kompetitifnya di pasar, ia harus memahami dimensi apa yang digunakan konsumen untuk membedakan produk yang dijual perusahaan dengan produk pesaingnya.

Kotler berpendapat bahwa loyalitas pelanggan didefinisikan sebagai kemungkinan pelanggan melakukan pembelian dan kesediaan mereka untuk menjadi mitra perusahaan (Kotler \& Keller, 2009). Loyalitas Tjiptono adalah komitmen pelanggan terhadap suatu toko, merek atau pemasok berdasarkan sikap positif yang tercermin dalam pembelian yang konsisten dan berulang.

Menurut Griffin (2009), loyalitas dapat didefinisikan atas dasar perilaku pembelian. Pelanggan setia adalah individu yang secara teratur membeli produk atau jasa, membeli antar lini produk atau jasa, merujuk kepada orang lain, dan menolak untuk menarik bisnis lain. Pandangan tentang loyalitas pelanggan, yang sering digunakan dalam penelitian selama ini, telah banyak berubah. Dalam bidang pemasaran, beberapa ilmuwan mengasosiasikan loyalitas pelanggan dengan loyalitas merek (Copeland, 1923 dalam Homburg dan Giering: 2001).

Pendapat Oliver lainnya dalam Uncle, Rowling dan Hammond (2003) mendefinisikan bahwa loyalitas konsumen adalah komitmen yang mendalam untuk membeli kembali atau berlangganan suatu produk atau jasa di masa yang akan datang, yang mengakibatkan pembelian berulang kali atas merek yang sama, meskipun dipengaruhi oleh situasi pemasaran dan yang dapat membawa aktivitas Anda ke halaman lain.

\section{Metode Penelitian}

Penelitian ini menggunakan metode deskriptif-verifikasi, sehingga akan diketahui ada tidaknya hubungan yang signifikan antara variabel-variabel yang diteliti, sehingga dapat ditarik kesimpulan yang menjelaskan gambaran objek yang diteliti.

Metode penelitian deskriptif adalah penelitian yang bertujuan untuk memperoleh gambaran atau gambaran tentang ciri-ciri tertentu (variabel tertentu) dari subjek yang diperhitungkan dalam kegiatan penelitian (Nuryaman dan Christina, 2015), sedangkan metode penelitian deskriptif menurut (Sugiyono, 2017) adalah metode penelitian yang digunakan untuk menggambarkan atau menganalisis hasil pengujian, tetapi tidak untuk menarik kesimpulan yang lebih luas.

Subyek penelitian dalam penyusunan makalah ini adalah konsumen PT Shafira Corporation di fasilitas Shafira Buah Batu Bandung. Dalam penelitian ini, penulis menyelidiki pengaruh harga dan kualitas produk terhadap loyalitas pelanggan, studi kasus PT Shafira Corporation pada Toko Shafira Buah Batu Bandung). Populasi dalam penelitian ini adalah jumlah konsumen PT Shafira Corporation yang tidak diketahui jumlahnya. Metode pengambilan sampel yang digunakan adalah tidak mungkin pengambilan sampel, dan peneliti mengikuti pendapat Malhotra, yang menyatakan bahwa jumlah besar sampel yang 
diambil dapat ditentukan dengan mengalikan 4 atau 5 kali jumlah elemen variabel yang diamati atau diamati (Malhotra, 2004).

Teknik pengambilan sampel yang digunakan dalam penelitian ini adalah Convenience Sampling. Menurut Sekaran, convenience sampling adalah mengumpulkan informasi dari anggota populasi yang bersedia memberikannya. Umumnya, responden dipilih karena mereka berada di tempat yang tepat pada waktu yang tepat (Sekaran, 2006).

\section{Uji Validitas}

Untuk mendukung analisis regresi dilakukan uji validitas dan reliabilitas. Uji relevansi adalah ukuran yang menunjukkan bahwa variabel yang diukur sebenarnya adalah variabel yang ingin diteliti oleh peneliti (Cooper dan Schindler dalam Zulganef, 2006) sedangkan Ghazali menyatakan bahwa uji validitas digunakan untuk mengukur validitas atau validitas kuesioner (Ghazali, 2009).

\section{Uji Reliabilitas}

Reliabilitas adalah alat untuk mengukur suatu kuesioner yang merupakan indikator dari variabel atau konstruk. Suatu kuesioner dikatakan reliabel atau handal jika jawaban seseorang terhadap pernyataan adalah konsisten atau stabil dari waktu ke waktu. Adapun cara yang digunakan untuk menguji reliabilitas kuesioner dalam penelitian ini adalah menggunakan rumus koefisien Cronbach Alpha. suatu konstruk atau variabel dikatakan reliabel jika memberikan nilai Cronbach Alpha $>0,60$ (Riduwan \& Akdon, 2007) hasil $\alpha>$ $0,60=$ reliabel dan hasil $\alpha<0,60=$ tidak reliabel. Untuk perhitungan dapat dilakukan dengan menggunakan program SPSS. Adapun rumus untuk uji Cronbach alpha, yaitu:

\section{$\alpha$}

Dimana:

$\alpha=$ koefisien keandalan alat ukur

$\mathrm{r}=$ koefisien rata-rata korelasi antara variabel

$\mathrm{k}=$ jumlah variabel

Pengertian analisis regresi linier berganda menurut Sugiyono adalah analisis yang digunakan peneliti, bila bermaksud meramalkan bagaimana keadaan (naik-turunnya) variabel dependen (kriterium). Bila dua atau lebih variabel independen sebagai faktor prediktor dimanipulasi (Sugiyono, 2017). Dalam penelitian ini, analisis regresi linier berganda digunakan untuk membuktikan sejauh mana hubungan pengaruh harga dan kualitas produk terhadap loyalitas pelanggan PT Shafira Corporation di Shafira Buah Batu Cab. Bandung.

Persamaan analisis regresi linier berganda secara umum untuk menguji hipotesis dalam penelitian ini adalah sebagai berikut:

$$
\mathrm{Y}=\alpha+\beta_{1} \mathrm{X}_{1}+\beta 2 \mathrm{X}_{2}+\varepsilon
$$

Dimana:

Y = Loyalitas Pelanggan 


$$
\begin{array}{ll}
\alpha & =\text { Konstanta } \\
X_{1} & =\text { Harga } \\
X_{2} & =\text { Kualitas Produk } \\
\beta_{1} & =\text { Koefisien regresi untuk variabel harga } \\
\beta_{2} & =\text { Koefisien regresi untuk variabel kualitas produk } \\
\varepsilon & =\text { Error Term }
\end{array}
$$

\section{Hasil dan Pembahasan}

Di bawah ini adalah hasil dari jawaban responden yang dinyatakan dengan angka dalam tabel kerja dengan rincian sebagai berikut:

a. Berdasarkan Jenis Kelamin

Mayoritas responden sebanyak 47 orang atau 31\% adalah responden laki-laki dan sebanyak 103 orang atau $69 \%$ adalah responden perempuan.

b. Berdasarkan Umur

Responden yang berumur $<20$ tahun sebanyak 8 orang atau $5 \%$, responden yang berumur 21-30 tahun sebanyak 84 orang atau 56\%, responden yang berumur 31-40 tahun sebanyak 25 orang atau 17\%, respons yang berumur 41-50 tahun sebanyak 14 orang atau 9\%, responden yang berumur 51-60 tahun sebanyak 4 orang atau 4\% dan responden yang berumur $>60$ tahun sebanyak 2 orang atau 1\%. Dapat disimpulkan bahwa mayoritas pelanggan yang terbanyak mengisi kuesioner adalah responden yang berumur 21-30 tahun sebanyak 84 orang atau $56 \%$.

c. Berdasarkan Pekerjaan

Responden pelajar/mahasiswa ada sebanyak 16 orang atau $11 \%$, responden Pegawai Negeri/TNI/POLRI sebanyak 42 orang atau 28\%, responden Pegawai Swasta sebanyak 66 orang atau 44\%, responden wiraswasta sebanyak 21 orang atau $14 \%$ dan sebanyak 5 orang atau 3\% responden lainnya. Dari tabel tersebut dapat disimpulkan bahwa responden terbanyak adalah responden pegawai swasta yaitu sebanyak 66 orang atau 44\%.

d. Pendidikan Responden

88 orang atau 59\% adalah responden yang pendidikannya S1. Sebanyak 34 orang atau $23 \%$ adalah responden yang pendidikannya S2, sisanya sebanyak 22 orang atau 15\% adalah responden yang pendidikannya diploma, 5 orang atau 3\% adalah responden yang pendidikannya S3 dan 1 orang atau 1\% adalah responden yang pendidikannya SMA.

\section{e. Pendapatan Responden}

Mayoritas responden sebanyak 68 orang atau 45\% adalah responden dengan pendapatan antara Rp. 5.000.000,- s/d Rp. 10.000.000,-, sebanyak 39 orang atau $26 \%$ adalah responden yang pendapatannya antara Rp. 10.000.000,- s/d Rp. 15.000.000,-, sebanyak 32 orang atau $21 \%$ adalah responden yang pendapatannya $<$ Rp. 5.000.000,-, sisanya sebanyak 8 orang atau 5\% adalah responden yang pendapatannya antara Rp. 15.000.000,- s/d Rp. 20.000.000,- dan sebanyak 3 orang atau $2 \%$ adalah responden yang pendapatannya $>\mathrm{Rp}$. 
Nisa Septiani

20.000.000.

Tabel Skala Pengukuran Variabel

\begin{tabular}{lc}
\multicolumn{1}{c}{ Pernyataan } & Nilai \\
\hline Sangat Tidak Setuju & 1 \\
\hline Tidak Setuju & 2 \\
\hline Netral & 3 \\
\hline Setuju & 4 \\
\hline Sangat Setuju & 5 \\
\hline
\end{tabular}

Sumber: Nur Nyaman dan Christina (2015:93)

Rumus yang digunakan untuk variabel $\mathrm{X}$ dan $\mathrm{Y}$ adalah sama yaitu sebagai berikut:

Panjang Kelas Interval $=\quad$ Rentang

Banyak Kelas Interval

Keterangan:

Rentang = Nilai Tertinggi - Nilai Terendah

Berdasarkan rumus di atas, maka panjang kelas interval adalah:

Panjang Kelas Interval $=\underline{5-1}=0,8$

5

Maka dapat ditetapkan interval sebagai berikut:

Tabel Interpretasi Skor

\begin{tabular}{cc}
\hline Pilihan Jawaban Pertanyaan & Bobot atau Skor \\
\hline $1,00-1,79$ & Sangat Tidak Setuju \\
\hline $1,80-2,59$ & Tidak Setuju \\
\hline $2,60-3,39$ & Kurang Setuju \\
\hline $3,40-4,19$ & Setuju \\
\hline $4,20-5,00$ & Sangat Setuju \\
\hline
\end{tabular}

Tabel Rekapitulasi Tanggapan Responden Terhadap Variabel Harga $\left(\mathrm{X}_{1}\right)$

\begin{tabular}{|c|c|c|c|c|c|c|c|c|}
\hline & \multirow{2}{*}{ Pernyataan Xl } & \multicolumn{5}{|c|}{ Alternatif Jawaban } & \multirow{2}{*}{ Rata-rata } & \multirow{2}{*}{ Ket } \\
\hline & & SS & $\mathrm{S}$ & KS & TS & STS & & \\
\hline & 1 & 12 & 116 & 19 & 3 & 0 & 3.91 & Setuju \\
\hline & 2 & 41 & 97 & 8 & 4 & 0 & 4.16 & Setuju \\
\hline \multirow{5}{*}{ atau be } & 3 & 29 & 115 & 3 & 3 & 0 & 4.13 & Setuju \\
\hline & 4 & 18 & 129 & 3 & 0 & 0 & 4.10 & Setuju \\
\hline & 5 & 27 & 121 & 2 & 0 & 0 & 4.16 & Setuju \\
\hline & 6 & 27 & 117 & 6 & 0 & 0 & 4.14 & Setuju \\
\hline & 7 & 23 & 120 & 5 & 2 & 0 & 4.09 & Setuju \\
\hline Jurnal & & & & & & & 4.10 & Setuju \\
\hline
\end{tabular}


yang menyatakan setuju dengan harga yang ditawarkan oleh PT Shafira Corporation. Harga merupakan faktor krusial dalam sebuah bisnis, salah satu keberhasilan PT Shafira Corporation adalah mampu mensegmentasikan dirinya menjadi toko busana muslim yang terjangkau oleh kalangannya.

Tabel Rekapitulasi Tanggapan Responden Terhadap Variabel Kualitas Produk $\left(\mathbf{X}_{2}\right)$

\begin{tabular}{|c|c|c|c|c|c|c|c|}
\hline \multirow{2}{*}{ Pernyataan Xl } & \multicolumn{5}{|c|}{ Alternatif Jawaban } & \multirow{2}{*}{ Rata-rata } & \multirow{2}{*}{ Ket } \\
\hline & SS & $\mathrm{S}$ & KS & TS & STS & & \\
\hline 1 & 29 & 106 & 14 & 1 & 0 & 4.08 & Setuju \\
\hline 2 & 24 & 97 & 22 & 7 & 0 & 3.92 & Setuju \\
\hline 3 & 19 & 81 & 43 & 7 & 0 & 3.74 & Setuju \\
\hline 4 & 37 & 79 & 22 & 12 & 0 & 3.94 & Setuju \\
\hline 5 & 34 & 95 & 21 & 0 & 0 & 3.94 & Setuju \\
\hline 6 & 43 & 88 & 14 & 5 & 0 & 4.12 & Setuju \\
\hline 7 & 33 & 94 & 20 & 3 & 0 & 4.04 & Setuju \\
\hline & & & & & & 3.97 & Setuju \\
\hline
\end{tabular}

Dari Tabel di atas tampak bahwa rata-rata jawaban responden berada pada range 3,97 atau berada pada pernyataan setuju. Hal ini dapat dilihat dari jawaban positif 150 responden yang menyatakan setuju dengan kualitas produk PT Shafira Corporation. Salah satu keberhasilan PT Shafira Corporation adalah mampu mensegmentasikan dirinya menjadi toko busana muslim dengan kemampuan produk yang diantaranya memiliki kehandalan, daya tahan, dan struktur keindahan desainnya.

Tabel Rekapitulasi Tanggapan Responden Terhadap Variabel Loyalitas Pelanggan (Y)

\begin{tabular}{|c|c|c|c|c|c|c|c|}
\hline \multirow{2}{*}{ Pernyataan X1 } & \multicolumn{5}{|c|}{ Alternatif Jawaban } & \multirow{2}{*}{ Rata-rata } & \multirow{2}{*}{ Ket } \\
\hline & SS & $\mathrm{S}$ & KS & TS & STS & & \\
\hline 1 & 36 & 95 & 17 & 2 & 0 & 4.10 & Setuju \\
\hline 2 & 6 & 108 & 36 & 0 & 0 & 3.80 & Setuju \\
\hline 3 & 8 & 114 & 25 & 3 & 0 & 3.84 & Setuju \\
\hline 4 & 8 & 114 & 28 & 0 & 0 & 3.86 & Setuju \\
\hline 5 & 11 & 116 & 21 & 2 & 0 & 3.90 & Setuju \\
\hline 6 & 8 & 120 & 22 & 0 & 0 & 3.90 & Setuju \\
\hline 7 & 9 & 110 & 31 & 0 & 0 & 3.85 & Setuju \\
\hline & & & & & & 3.89 & Setuju \\
\hline
\end{tabular}

yang menyatakan setuju bahwa akan datang kembali ke toko Shafira berada pada range 3,89.

\section{Uji Normalitas}

Uji normalitas pada model regresi bertujuan untuk menguji apakah nilai residual terdistribusi secara normal atau tidak. Jadi dalam hal ini yang diuji bukan masing-masing variabel independen dan dependen tetapi nilai residual yang dihasilkan dari model regresi. Model regresi yang baik adalah memiliki nilai residual yang terdistribusi secara normal dengan melihat penyebaran data pada sumber diagonal pada grafik Normal P-P Plot of 
Nisa Septiani

regression standardized atau dengan uji One Sample Kolmogorov Smirnov (Ghozali, 2010).

One-Sample Kolmogorov-Smirnov Test
\begin{tabular}{|ll|r|}
\hline & & $\begin{array}{c}\text { Unstandar dized } \\
\text { Residual }\end{array}$ \\
\hline N & 20 \\
Norma1 Parameterg'v & Mean & 30.566 \\
& Standard & \\
Most Extreme & Deviation & 5.03762 \\
Differences & Absolute & 0.176 \\
& Positive & 0.15 \\
Kolmogorov-Smirnov Z & & -0.176 \\
Asymp. Sig.(2-tailed) & & 0.786 \\
& Negative & 0.567 \\
\hline
\end{tabular}

Berdasarkan uji normalitas dengan Kolmogorov-Smirnov Test diperoleh nilai Asymp.sig. sebesar 0,567 lebih besar dari 0,05 maka dapat disimpulkan bahwa data berdistribusi normal.

\section{Pengujian Hipotesis Parsial (Uji-t)}

Dengan menggunakan program SPSS diperoleh output sebagai berikut :

Uji-t

\begin{tabular}{|c|c|c|c|c|c|}
\hline \multicolumn{6}{|c|}{ Coeficients ${ }^{2}$} \\
\hline \multirow[b]{2}{*}{ Mode1 } & \multicolumn{2}{|c|}{$\begin{array}{l}\text { Unstanderdized } \\
\text { Coeficients }\end{array}$} & \multirow{2}{*}{$\begin{array}{c}\text { Srandardized } \\
\text { Coeficients } \\
\text { Beta }\end{array}$} & \multirow[b]{2}{*}{$\mathrm{t}$} & \multirow[b]{2}{*}{ Sig } \\
\hline & B & $\begin{array}{l}\text { Std. } \\
\text { Eror }\end{array}$ & & & \\
\hline 1 (Constant) & 4.326 & 3943 & & 1.097 & 270 \\
\hline Herge & 298 & .150 & .319 & 1.984 & .004 \\
\hline Kualites Produk: & .560 & .146 & .619 & 3.844 & .001 \\
\hline
\end{tabular}

\section{Pengujian hipotesis variabel $X_{1}$ (Harga)}

$\mathrm{H}_{0}=$ harga tidak berpengaruh signifikan terhadap loyalitas pelanggan

$\mathrm{H}_{1}=$ harga berpengaruh signifikan terhadap loyalitas pelanggan

Tingkat signifikan $(\alpha)$ sebesar 5\%, dan derajat kebebasan $(\mathrm{v})=17(\mathrm{n}-(\mathrm{k}+1))$ dan $\mathrm{V}_{2}$

$=2$ didapat nilai $\mathrm{t}$ tabel 1,976

\section{Pengujian hipotesis variabel X2 (Kualitas Produk)}

$\mathrm{H}_{0}=$ kualitas produk tidak berpengaruh signifikan terhadap loyalitas pelanggan

$\mathrm{H}_{1}=$ kualitas produk berpengaruh signifikan terhadap loyalitas pelanggan Tingkat signifikan $(\alpha)$ sebesar 5\%, dan derajat kebebasan $(\mathrm{v})=17(\mathrm{n}-(\mathrm{k}+1))$ dan $\mathrm{V}_{2}=2$ didapat nilai $\mathrm{t}$ tabel 1,976 


\section{Pembahasan Masalah}

1. Hasil uji $\mathrm{F}$ memperlihatkan bahwa harga dan kualitas produk berpengaruh signifikan terhadap loyalitas pelanggan. Hal tersebut ditunjukkan dari nilai F Hitung sebesar 23,333 dengan p-value (sig) 0,000. Sementara itu, dari hasil perhitungan koefisien korelasi diperoleh $\mathrm{R}$ sebesar 0,856 sehingga dapat disimpulkan bahwa antara variabel terikat dengan seluruh variabel bebas memiliki hubungan yang kuat. Dari hasil perhitungan Koefisien Determinasi diperoleh nilai $\mathrm{R}^{2}$ sebesar $(0,856)^{2}$ maka dapat disimpulkan bahwa variabel bebas dalam penelitian ini mampu menerangkan 73,27\% mengenai harga dan kualitas produk. Sedangkan sisanya $26,73 \%$ dipengaruhi oleh variabel lain yang tidak diamati di dalam penelitian ini.

2. Pengaruh Harga terhadap loyalitas pelanggan.

Hasil pengujian hipotesis harga $\left(\mathrm{X}_{1}\right)$ mendapatkan bahwa variabel harga berpengaruh signifikan terhadap loyalitas pelanggan. Hasil penelitian ini mendapatkan bahwa harga yang ditawarkan terjangkau oleh semua golongan khususnya segmen pendapatan menengah ke atas, sehingga konsumen berkomitmen untuk kembali lagi ke took Shafira.

3. Pengaruh Kualitas produk terhadap loyalitas pelanggan.

Hasil pengujian hipotesis kualitas produk $\left(\mathrm{X}_{1}\right)$ mendapatkan bahwa variabel kualitas produk berpengaruh signifikan terhadap loyalitas pelanggan. Hal ini berarti konsumen akan memilih kualitas produk yang baik. Dalam penelitian ini konsumen Shafira menilai bahwa produk Shafira memiliki kualitas produk yang baik. Hasil penelitian ini mendapatkan bahwa dalam banyak hal kualitas produk Shafira sudah sesuai dengan kriteria yang sebagaimana diharapkan oleh konsumen, dimana dalam hal ini konsumen mengharapkan kualitas produk yang baik.

\section{Kesimpulan}

Berdasarkan hasil penelitian terhadap variabel harga (X1) diketahui bahwa rata-rata responden memberikan jawaban yang konsisten terhadap kuesioner mengenai harga dengan rata-rata jawaban responden pada kisaran 4,10. Berdasarkan hasil penelitian terhadap variabel kualitas produk (X2) didapatkan bahwa rata-rata responden memberikan jawaban yang konsisten terhadap kuesioner mengenai kualitas produk dengan rata-rata jawaban responden pada kisaran 3,97.

Dari hasil survey pada variabel loyalitas pelanggan (Y), rata-rata responden setuju dengan isi kuesioner yang diberikan dengan rata-rata jawaban responden pada kisaran 3,89. Terdapat pengaruh terhadap loyalitas pelanggan terhadap harga produk PT Shafira Corporation. Terbukti diperoleh nilai koefisien determinasi $(\mathrm{R}$ square $=0,3192)$ sebesar 0,192 atau 19,26 yang artinya harga hanya memberikan kontribusi sebesar 19,26\% dalam menentukan loyalitas pelanggan PT Shafira Corporation.

Kualitas produk PT Shafira Corporation mempengaruhi loyalitas pelanggan. terbukti koefisien determinasi yang diperoleh $(\mathrm{R}$ kuadrat $=0,6192)$ adalah 0,402 yang berarti kualitas 
Nisa Septiani

produk memberikan kontribusi 40,20\% terhadap determinasi loyalitas pelanggan PT Shafira Corporation. 


\section{BIBLIOGRAFI}

Alma, Buchari. (2005). Manajemen Pemasaran dan Pemasaran Jasa, Cetakan. Bandung CV Alfabeta. Google Scholar

Christopher, Zerres. \& Reinhard Huneberg. 2009. The Perceived Benefits of Price Related Promotion and the Impact of Consumer Price Knowledge. The Case of The German Automobile Market. Anzmac. Google Scholar.

Dinawan, M. Rendhia. 2010. Analisis faktor-faktor yang mempengaruhi keputusan pembelian (Studi kasus pada konsumen Yamaha Mio PT Harpindo Jaya Semarang). Tesis MM Universitas Diponegoro, Semarang. Google Scholar.

Ghozali, Imam. (2010). Aplikasi Analisis Multivariate Dengan Program SPSS, Edisi Keempat, Penerbit Universitas Diponegoro. International, Inc, New Jersey. Google Scholar

Hurriyati, Ratih, 2005. Bauran Pemasaran dan Loyalitas Pemasaran. Bandung, Alfabeta. Google Scholar

Heryanto, Imam. 2015. Analisis pengaruh produk, harga, distribusi dan promosi terhadap keputusan pembelian serta implikasinya pada kepuasan pelanggan. Jurnal ekonomi \& bisnis vol. 9, No. 2, ISSN 2443-2121 Howard, J.A. and Shay, R. P. 1988. "Measuring The Effect of Marketing Information on Buying Intention. The Journal of Service Marketing, Vo. 2, No. 4 Fall. P.27-36. Google Scholar.

Kotler, Philip, \& Keller, Kevin Lane. (2009). Manajemen Pemasaran, Edisi 13. Jakarta: Erlangga, 14. Google Scholar.

Malhotra, Naresh K. 2004. Marketing Research: An Applied Orientation, Pearson Education, Inc., Fifth Edition, New Jersey, USA. Google Scholar.

Nazir, Moh., 2011. Metode Penelitian. Jakarta. Ghalia Indonesia. Google Scholar.

Nurhayati, 2011. "Pengaruh Kualitas Produk dan Harga Terhadap Loyalitas Pelanggan (Pengguna Handphone Merek Nokia)" Google Scholar.

Nuryaman dan Christina, V. 2015. Metodologi penelitian Akuntansi dan Bisnis, Bogor: Ghalia Indonesia. Google Scholar

Riduwan, Akdon, \& Akdon, A. (2007). Rumus dan data dalam analisis statistika. Bandung: Alfabeta. Google Scholar. 
Nisa Septiani

Sekaran, U. (2006). Metodologi Penelitian Untuk BisnisJakarta. Salemba Empat. Google Scholar.

Stanton, William J. 2000, Prinsip-prinsip Pemasaran, Jilid I Edisi ke 3, Alih Bahasa Oleh Yohanes Lamarto, Jakarta: Erlangga. Google Scholar.

Sugiyono. 2011. Metode Penelitian Pendidikan. Bandung: Alfabeta. Google Scholar.

Tjiptono, Fandy, 2008. Strategi Pemasaran. Cetak Ketiga, Yogyakarta: Andi. Google Scholar.

Ulfa, 2012, "Pengaruh Kualitas Pelayanan, Harga dan Lokasi Terhadap Loyalitas Pelanggan di Penginapan Mega Syariah Semarang”. Google Scholar.

Zulganef. 2008. Metode Penelitian Sosial dan Bisnis. Yogyakarta: Graha Ilmu. Google Scholar. 